\title{
Some Thoughts on the Administration of the Regional Development in the Member States of the EU - In the Light of the Role of the Municipal Bodies
}

\author{
István Hoffman \\ Eötvös Loránd University (Budapest), Faculty of Law, Department of \\ Administrative Law, Hungary \\ hoffman.istvan@ajk.elte.hu
}

\section{ABSTRACT}

Municipalities are traditionally responsible for several regional planning and development tasks even if different systems have evolved in the Member States of the European Union. The administration of regional planning has been strongly influenced by the European integration. The allocation of the European Structural and Investment Funds was a major task of the recipients. The regional approach of the structural funds was a catalyst for the territorial reforms in several EU Member States. Although originally the regional reforms were based on the NPM-related reforms the changes were supported by the post-NPM paradigms (especially by the Good Governance paradigm) as well. In several countries the Crisis caused centralisation and the concentration of the structures. Thus three major models could be distinguished: centralised regional development systems, decentralised systems and federal systems. The characteristics of these systems are reviewed in the article focusing on their major differences and similarities.

Keywords: centralisation, decentralisation, European Structural and Investment Funds, federalism, municipalities, regional development

JEL: 118

\section{Introduction}

The significance of the public administration increased in the field of the regional development in the last decades. Not only the nation states but the supranational integrations had important competencies in the regional development. In Europe the European Union became an outstanding actor of the regional policies (see Table 1 ).

1 This article was supported by the János Bolyai Research Scholarship of the Hungarian Academy of Sciences. This article is part of the research project "New tendencies of regulating the Single Market and their effects on the organization and functioning of public administration" No. OTKA K 112550 (leader of the project: Prof. Dr. Marianna Nagy). 
Table 1 Resources for economic, social and territorial cohesion in the EU (2014-2020)

\begin{tabular}{|l|c|}
\hline \multicolumn{1}{|c|}{ Aim } & Resource (in 2011 prices) \\
\hline $\begin{array}{l}\text { Resources for economic, social and territorial } \\
\text { cohesion (2014-2020) in the EU }\end{array}$ & EUR 325145694739 \\
\hline $\begin{array}{l}\text { - from this allocated to the European } \\
\text { Regional Development Fund (ERDF), } \\
\text { the European Social Fund (ESF) and the } \\
\text { Cohesion Fund }\end{array}$ & EUR 322145694739 \\
\hline $\begin{array}{l}\text { - From this allocated for Youth Employment } \\
\text { Initiative (YEI) }\end{array}$ & EUR 3 000 000000 \\
\hline
\end{tabular}

Source: Art. 91(1) of Regulation (EU) No 1303/2013

Because of the prominent role of the public administration the administrative structures of the management of the regional development is an important topic. The phenomenon of the regionalism, ${ }^{2}$ the role of the EU and its regional development strategies ${ }^{3}$ and the political economy of the regionalism ${ }^{4}$ are recent topics of the analysis as well as the structure and characteristics of the different regional development bodies and agencies. ${ }^{5}$ The local governance and the local policy making procedures have been analysed by several volumes and articles. These analyses focused on the economic and policy-making ('governance') issues of the topic and has only been reviewed by the jurisprudence partly.

Therefore the comparison of the legal regulations on the role of the local governments in the field of the regional development can offer a different view on a topic which is analysed in detail. The impact of the legal system of the given countries and the influence of the legislation of the European Union can be observed by this approach, as well. In the new Member States and in the Mediterranean countries this influence is more significant, because their regional units are mainly less developed and transition regions. These regions are the main primary recipients of the EU funds (see Table 2).

2 The regional reforms and the post-regionalisation is analysed in detail in several articles, see for example Sharpe, 1993, Borras-Alomar et al., Jeffrey, 1997., Martin, 1999., Magone, 2003. On the post-regionalisation see for example Schrijver, 2006.

3 See for example Marks, 1992, Loughlin, 1997, and McCann 2015.

4 See for example Keating \& Loughlin, 1997.

5 See for example Halkier et al., 1998. 
Table 2 Allocations of the resources for the Investment for growth and jobs goal (2014-2020)

\begin{tabular}{|l|l|}
\hline \multicolumn{1}{|c|}{ Regions } & \multicolumn{1}{|c|}{ Allocation of the resources } \\
\hline Less developed regions & $52,45 \%$ (EUR 164 279 015 916) \\
\hline Transition regions & $10,24 \%$ (EUR 32084931311 ) \\
\hline More developed regions & $15,67 \%$ (EUR 49084308755$)$ \\
\hline $\begin{array}{l}\text { Cohesion Fund (for the given } \\
\text { Member States) }\end{array}$ & $21,19 \%$ (EUR 66362384703 ) \\
\hline $\begin{array}{l}\text { Additional funding for the outermost } \\
\text { regions identified in Article 349 TFEU }\end{array}$ & $0,44 \%$ (EUR 1386794724$)$ \\
\hline Total & $100 \%$ (EUR 313197435 409) \\
\hline
\end{tabular}

Source: Art 92(1) of Regulation (EU) No 1303/2013

\section{Methods and Hypothesis}

The analysis is focused on the legal regulations on the organisation and the powers and duties of the local and regional governments. Therefore the main question of the analysis is the centralised and decentralised approach of the national systems. A preliminary question is the approach of the centralisation. The definition of centralisation is contradictory. In classical administrative jurisprudence centralisation is interpreted as a concept by which the unity of the administration is ensured (Kuhlmann and Wollmann, 2014, pp. 119-121). In the traditional jurisprudential approach the centralisation is closely linked to the tasks of the central administration. This legal approach is problematic in the federal states, where the federal units are interpreted as units with statehood. Therefore legally the federal states could have a centralised systems, because in these countries the most important actors in the field of regional development are the member states of the federations (Вäumer \& Кгоёs, 2016, pp. 63-64). These entities - for example the Austrian Länder-are interpreted as subnational units by the approach of the comparative governance. The subnational and therefore regional-like status is emphasized by the comparative governance however these units have legally central administration because they have statehood. Therefore - legally - these systems can be interpreted as centralised systems from the point of view of the municipal tasks.

Three main models will be distinguished by the analysis: firstly the centralised model, secondly the decentralised model and thirdly the federal model. 
Table 3 Overview of the main models of the administration of the regional development

\begin{tabular}{|c|c|c|}
\hline Centralised model & Decentralised model & Federal model \\
\hline $\begin{array}{l}\text { Centralised systems } \\
\text { (Slovenia, Greece, } \\
\text { Lithuania, Estonia) }\end{array}$ & $\begin{array}{l}\text { Regional development } \\
\text { administration based } \\
\text { on regional ( } 3^{\text {rd }} \text { tier) } \\
\text { governments (France, } \\
\text { Italy, Poland, Bavaria) }\end{array}$ & $\begin{array}{l}\text { Regional planning } \\
\text { centralised by the } \\
\text { member states of the } \\
\text { federation (Austria, } \\
\text { smaller German } \\
\text { provinces) }\end{array}$ \\
\hline $\begin{array}{l}\text { Centralised hybrid systems: } \\
\text { - Centralised regulation } \\
\text { with regional } \\
\text { development councils } \\
\text { (Czech Republic, Latvia) } \\
\text { - Transition to the } \\
\text { decentralised systems: } \\
\text { inter-municipal } \\
\text { associations as } \\
\text { managing authorities } \\
\text { (Ireland before 2000) }\end{array}$ & $\begin{array}{l}\text { Between federalism and } \\
\text { decentralisation: } \\
\text { - A "quasi" or "de-facto" } \\
\text { federation and the } \\
\text { regional development } \\
\text { (Spain) } \\
\text { - An asymmetrical } \\
\text { federation (?) (United } \\
\text { Kingdom) }\end{array}$ & $\begin{array}{l}\text { Federal models with } \\
\text { shared competences } \\
\text { between state and local } \\
\text { government (majority of } \\
\text { the German provinces, } \\
\text { Belgium) }\end{array}$ \\
\hline \multicolumn{3}{|l|}{$\begin{array}{l}\text { Transition to the } \\
\text { decentralised systems: } \\
\text { inter-municipal } \\
\text { associations as managing } \\
\text { authorities (Ireland, } \\
\text { Portugal) }\end{array}$} \\
\hline $\begin{array}{l}\text { Centralised systems with } \\
\text { partial competences of } \\
\text { the regional ( } 2^{\text {nd }} \text { tier local) } \\
\text { governments (Sweden, } \\
\text { Slovakia, Hungary) }\end{array}$ & & \\
\hline
\end{tabular}

\section{Results and Discussions: Regulation on the Organisation of the Regional Development in Europe}

\subsection{Centralised Model (In Small Countries)}

The centralised model is based on the determinative role of the central government and its agencies. In this model the local and regional governments have several competencies in the field of regional development and planning. Although the municipalities can have important tasks in the field of planning the majority of the policy-making responsibilities - especially the preparation and approval of the major plans and the management of the allocation of the development funds - are centralised.

Firstly in several countries hybrid bodies have evolved which mainly belong to the central administration but the inclusion of the local and regional govern- 
ments in the decision-making process is enabled by this regulation. Secondly the major planning and the resource allocation duties and responsibilities typically in the field of the management of the EU development funds - are centralised, but the regional governments of these countries have important planning competencies.

\subsubsection{Centralised Systems}

The centralised systems are based on the determinative tasks and powers of the central government and its agencies.

This model is followed by the small Member States of the European Union, especially by the countries which have a one-tier local government system. This type of centralised model has evolved in Slovenia. The country is divided into 212 municipalities which are classified as LAU-2 units, therefore they could not perform regional development tasks independently. Although these municipalities take part in the decision-making of the regional development (Deželan et al., 2014, pp. 547-573.), the regional development policy belongs to the competences of the central government (Ravšelj \& Aristovnik, 2017, p. 80). In Slovenia, regional and subregional development agencies have been organised. These agencies have professional staffs, and they assist the municipalities in fulfilling their development goals. However, these bodies could be considered as the special agencies of the central government (Ploštajner, 2005, p. 227).

Similarly, Lithuania and Estonia have a one-tier system and thus their regional development administration is strongly centralised. In Estonia and Lithuania these tasks are performed primarily by the ministries responsible for regional development and local government (Adams, 2006. p. 162, Hooghe et al, 2016, pp. 438-440).

Although the Greek $2^{\text {nd }}$ tier local governments have several planning competences the Greek regional development administration is strongly centralised, especially the allocation of the EU funds belongs to the central government and its agencies (Christopoulos, 1999, pp. 158-159 and Hooghe et al, 2016, pp. 468-472).

\subsubsection{Centralised Hybrid Systems}

The centralised hybrid models have evolved in the late 1990s. This model is based on a centralised national system combined with a bottom-up planning model.

\subsubsection{Centralised Regulation with Regional Development Councils}

In this model the planning is centralised, the major decisions are made by the central government. Although the first and the second tier local governments have some planning tasks and responsibilities, but in the NUTS-2 level special hybrid bodies are organised. 
This model was applied by Hungary formerly. In 1996/1997 when the Act XXI of 1996 on the Regional Development and Spatial Planning was passed the regional development tasks were delegated to special hybrid bodies, to the County Development Councils (megyei területfejlesztési tanács). These bodies were originally tripartite bodies: the local and the central government and the social partners in the counties could delegate the members of the councils. In 2001 the former tripartite nature of the County Development Councils changed: the members of these councils were the delegates of the central government and the local governments. By this reform - regarding to the pre-accession procedure and the Agenda 2000 reforms of the EU funds - 7 NUTS-2 level Regional Development Councils were established, because the 19 Hungarian counties were NUTS-3 units (Pálné Kovács, 2014, pp. 97-100). These bodies were bipartite bodies, like the County Development Councils. The tasks of the managing authorities were fulfilled by the ministries and the agencies of the central government (Szalai, 2004, pp. 230-233). After the municipal reforms in 2011/12 this model was changed and a centralised system with developing $2^{\text {nd }}$ tier local governments evolved.

The Czech model is a transition to the inter-municipal one: in 20028 NUTS-2 level Regional Council was established. The members of the Regional Councils are the delegates of the 14 second tier local government, the NUTS-3 level county governments (kraje). The Regional Councils could be considered as special inter-municipal cooperation and the managing authorities are the bodies of these regional organisations. The hybrid element of the Czech system is the centralised planning procedure and the supervisory competences of the central government (Piattoni, 2008, 174-175).

A similar model has evolved in Latvia - which has a one-tier municipal system - where the Regional Development Law of 2002 established special, hybrid bodies in the planning regions (Tatham, 2016, p. 261).

\subsubsection{Transition to the Decentralised Systems: Inter-Municipal Associations as Managing Authorities}

One of the most typical examples is the model of Ireland. Ireland was in the 1970s one of the poorest states in Western Europe. After 1973, after the Accession of Ireland to the European Economic Community and the expansion of the European cohesion policy, this country received significant European development funds. First of all, the administration and management of the planning and the allocation of the European funds has been centralised, the managing authorities were practically the agencies of the central government. The New Public Management paradigm and later the Good Governance paradigm impacted the Irish regional development model (MacCarthaigh, 2017, pp. 6-7): the reforms in the 1990s aimed to decentralise the system. Firstly, the municipalities were obliged to establish Local Development Boards which became the actors of the planning policy. In 2000 the City and County Development Boards were established which are the special committees of the 
given county and city local government, but they are guided by a member of the central government's Local Development Liaison Team (Adshead, 2003, pp. 119-122). Thus these boards are practically hybrid bodies. In the 1990s taking into account the regionalisation tendencies - two special bodies were established: the two regional assemblies, which are practically the managing authorities of the operative programs based on the European Regional Development Fund and the European Social Fund. These bodies are not considered as an independent regional tier by the Irish administrative law: the members of the assemblies are not elected but delegated by the municipalities and the county and city councils and they do not have general powers - unlike the Irish local governments (Callanan, 2003, pp. 437-438). Because of these special characteristics, these bodies can be interpreted as special inter-municipal associations of the Irish first and second tier local governments. Although the national planning has remained centralised, the regional development became decentralised, thus a transition model have evolved. This model remained after the transformation of the Irish economy. Now Ireland is a relatively rich Member State of the European Union: in 2016 the Irish GDP per capita is $177 \%$ of the average of the EU-28 (Eurostat, 2017) and therefore the Irish regions are classified as more developed regions. Thus the decentralisation tendencies were parallel to the decrease of the significance of the EU funds in the Irish economy. In Ireland the bodies responsible for decision-making and for the executive tasks are mainly companies owned by the public bodies: the regional development agencies (Halkier, 2012, p. 47).

A similar model has evolved in Portugal: the managing authorities of the regional development are practically inter-municipal associations of the second-tier local governments. Practically, this task was a catalyst of the inter-municipal cooperation in Portugal which has not long tradition in the Southwestern country of the European continent (Teles, 2016, pp. 63-64). For decision making and the policy making tasks companies were established by these inter-municipal associations. The administrative functions are performed by companies owned by the public bodies (Halkier, 2012, p. 49).

\subsubsection{Centralised Systems with Partial Competences of the Regional ( $2^{\text {nd }}$ Tier Local) Governments}

In several countries the allocation of the regional development funds - especially the funds which are co-financed by the European Union - is centralised: the central government is responsible for these tasks. Therefore the managing authorities are bodies or agencies of the central government. The regional planning is partly centralised. This model is followed by the countries which have two-tier local government systems and the second tier local governments either are NUTS-3 units or they have limited competences.

This model is followed by the Republic of Slovakia. In 1996 eight regions (kraj) were established which are local governments and they have wide competences. The kraje are NUTS-3 units therefore they could not perform the tasks 
of the NUTS-2 units. Thus the Slovakian regions have several competences of the regional planning, but the majority of them belongs to the central government and its agencies (Malíková \& Jacko, 2016, pp. 289-290).

Similar model have evolved in Hungary after the municipal reform of 2012/2013. The Regional Development Councils were abolished. The majority of the competences of the regional development councils were transferred to the county governments (Hoffman, 2017, pp. 123-128 and Tosics, 2016, pp. 674-675). ${ }^{6}$ In Hungary the structure of the decision-making and executive tasks were transformed as well: until 2016 these tasks were performed by companies owned by the counties (regionális fejlesztési ügynökségek - regional development agencies) (Hoffman, 2015, pp. 126-127). The majority of these companies (six out of the seven regional development agencies) were nationalised and their tasks are now performed by the county offices of the Hungarian State Treasury and by the offices of the county governments (Hoffman, 2017, p. 130).

Similarly, the - NUTS-3 level - Swedish counties (län) have wide competences in the field of public services provision, but their tasks are very limited in the field of regional development (Johansson, 2000, p. 138). In the last decades the Swedish regional planning system became more decentralised. This decentralisation was influenced by the concept by the urban government, therefore the in the regional planning the urban-centred inter-municipal bodies have significant role (Giersig, 2008, p. 199).

The centralised model is based on the determinative role of the central government. Although the $1^{\text {st }}$ and $2^{\text {nd }}$ tier local governments have several competences the main policy-making competences belong to the central government and agencies. As a result of the New Public Management Reforms, the executive and decision-making bodies are often companies which are owned by the public bodies.

This model is followed mainly by small countries with one-tier system. Those countries which receive large amount from the EU funds prefer primarily the centralised model (Constantin et al., 2011, pp. 183-185). The system of the countries which were formerly important recipients of EU funding (Ireland, Portugal) have been partly decentralised after the Accession of the Eastern Central European New Member States to the European Union and now they belong to a practically mixed model. The Nordic countries could be interpreted as an exception from the above mentioned tendencies: although their municipalities have wide public service provision competences their regional planning and development structure is relatively centralised.

6 In 2011/12 the competences of the county governments transformed significantly. The former public service provision tasks of the county governments are fulfilled by the central government and its agencies, but the regional planning competences of the counties were strengthened, thus a new paradigm of the county governments, the paradigm of the "development counties" have been evolved (Hoffman, 2014, pp. 411-412). 


\subsection{Decentralised Model (In Larger Countries)}

The administration of the regional development was strongly influenced by the regionalisation and decentralisation tendencies in Europe (Kacziba et al., 2016, pp. 45-47). These tendencies had multiple effects on the structure of the regional development. Firstly, the administration of the allocation of the development resources and the spatial planning became more decentralised, secondly the regional tier of the municipal system was transformed. The regional development administration systems of the Member States of the European Union have been impacted differently by this tendency (Hughes et al., 2005, p. 128).

The decentralised model of regional planning is based on the determinative role of the regional governments. Obviously, the national (central) governments have the competences of the coordination of the regional planning, but the allocation of the regional development resources and the regional planning tasks belong to the competences of the regional (typically $2^{\text {nd }}$ or $3^{\text {rd }}$ tier local) governments. Therefore this model is closely related to regionalisation, because the decentralisation of the central government development tasks or the concentration of the former municipal development tasks was one of the key elements of the regional reforms (Loughlin et al., 2011, p. 12).

These regional reforms were different: in several cases quasi-federal units have evolved. This different type of regionalisation resulted in different levels of the decentralisation of the regional planning systems.

\subsubsection{Regional Development Administration Based on Regional ( $3^{\text {rd }}$ Tier) Governments}

The regionalisation tendency was based on the establishment or strengthening of the $3^{\text {rd }}$ tier local governments, the regions. The example of these reforms was the French regional reform from the 1960 s to present. Although the feudal France was based on the regions, the revolutionary and Napoleonic legislation introduced a centralised state and the regions - as the last resort of the 'ancien régime' - were abolished (Swann, 2012, p. 105). The new territorial units were the départements, the French counties, which had limited autonomy, the prefect (préfet) had significant supervisory powers.

Although the regions as administrative units were abolished the regional differences remained. Thus the regionalisation became an issue after the World War II. In 195522 planning regions (circonscriptions d'action régionale) were established, but these regions were part of the top-down planning structure. The next step of the regionalisation was the establishment of the regional prefect (préfet de region) in 1964 when the county prefects of the seat of the given regions received regional competences. Thus the territorial agencies of the central government were partly regionalised. These regional bodies had significant competences in the field of regional planning and development (Hooghe et al., 2016, p. 373). 
The decentralised model evolved by the reforms of the Loi Defferre (1982) when the regional governments as $3^{\text {rd }}$ tier local governments were established. Thus France have a two-tier regional government system: the first, lower tier is the level of the départements - which are NUTS-3 units - and the second, higher tier is the level of the regions - which are NUTS-2 units. These regions have a directly elected council. The majority of the competences of the regional préfet were transferred to the president of the regional council (Dantonel-Cor, 2007, pp. 35-38). One of the key issues of the French regional reforms was the decentralisation of the planning and development competences. The most important tasks and powers of the regional prefects were the competences on the allocation of the development resources. Although several allocation competences of the regional prefect remained, the major development tasks and powers were decentralised and now they are performed by the regional councils (Booth, 1996, p. 62).

Therefore the regions became the central bodies of the regional development. The regional - spatial - structure was significantly reformed in the last years: the former 21 mainland regions were merged into 12 mainland regions (the independent, special region status of Corsica and the five overseas regions were left unchanged). The powers of the regions have been strengthened by this reform, especially in the field of the public service provision. Because of the wide development competences the transformation has been just partially in this field (Marcou, 2015, pp. 26-30).

The French counties, the départements lost the majority of their development tasks, but several planning competences have remained. In the regionalised French system these units are the framework for the coordination of the planning activities of the first tier local governments. The fragmented municipal system has remained: there are more than 36500 first tier local units (communes), but the reform of the loi Chevènement in 1999 transformed the local framework significantly. The new inter-municipal associations concentrated the majority of the local planning and development competences (Wollmann \& Bouckaert, 2006, p. 11). Thus a decentralised, region-centred model has evolved in France, where the counties and $1^{\text {tt }}$ tier local government have just partial, planning competences. This French model was an example for the European regional reforms, especially in those countries which have followed the French model of public administration.

In Germany, Bavaria has a special status: the Bavarian system can be interpreted as a decentralised one, because the Bavarian districts (Bezirke) are regional governments, which have are primarily responsible for the regional planning and development (Weber \& Köppert, 2015, p. 27).

Although several countries tried to introduce regional reforms in the Eastern Central European countries, the only successful reform was the regionalisation of Poland. The Polish model was based on the French decentralisation pattern, but it was different in some respect. Firstly, the Polish reform was 
based on the merge of the former NUTS-3 level units, the Polish counties, the 49 Voivodeships (województwo) were merged into 16 large Voivodeships which are interpreted as NUTS-2 level units. These Voivodeships are the third tier local governments with wide powers and tasks (Józsa, 2005, p. 200). Following the French regional planning and development model the councils of the voivodeships and their elected officers are responsible for the regional planning and the allocation of the development funds - including the funds from the European Union. Thus these regional bodies are the managing authorities of the EU structural funds in the regions (Swianiewicz, 2013, pp. 335-336). The second tier local governments, the districts (powiat) are smaller units with limited planning competences. The local municipalities, the first tier units (gmina) only have local planning tasks. The central government is responsible for the several, national development projects and for the coordination of the regional development policies (Jagielski, 2005, pp. 173-177). The Polish model is a decentralised one, but the central government has relatively significant powers in the field of regional planning. Thus the Polish model could be intepreted as an exceptional one among the Eastern Central European New Member States of the European Union.

A similar model has evolved in Italy. In the $19^{\text {th }}$ century it was a strongly centralised, unitary state which was divided into provinces (provincia/province). The provincia was similar to the French département, it had a limited local government which was supervised by the prefect (prefetto) who was appointed by the central government (Cassese, 2010, pp. 254-255). The regional development and the planning was centralised, the province and the municipalities (comune) had partial competences only. Although the Italian state was centralised the regional differences and inequalities remained. The unitary nature of the Italian state has remained, the Republic of Italy is "one and indivisible" ("una e indivisibile") but the local and regional government system has been transformed after the World War II. Although the provinces (province) have been conserved by the administrative law, the regions (regione) were established. The regions became responsible for the tasks of regional planning and development and they are responsible for the allocation of the development fund - including the funds co-financed by the European Union. The regions have very wide autonomy, they have legislative powers. Unlike the French model, in Italy an asymmetrical regional system has evolved. Several regions have special status. This special status is related to the ethnic diversity (the German ethnic majority in Alto-Adige/Südtirol and the French ethnic majority in Valle d'Aosta/Vallée d'Aoste) and the traditional differences in Italy, especially the disparities between Northern and Southern Italy. Thus several regions have special competences - official status of the minority and regional languages or the widened powers of the regional governments in the field of regional development, taxation and public service provision (Franchini \& Vesperini, 2012, pp. 108-111). The significance of the regions have been strengthened after 2014 when the competences of the province were weakened, and the direct election of the provincial assemblies and the provincial 
councils (giunta provinciale) as municipal organs were abolished by the legge Delrio (legge 7 aprile 2014, $n$ 56). The competences and the autonomy of the metropolitan cities have been strengthened by this act, as well (Amorosi \& Cinque, 2015, p. 367). Thus the Italian regions have a very strong autonomy: it is highlighted by the literature that Italy is a regionalised state, because the regions have more competences than a regional municipality but have less powers than the member states of a federative state (Mangiamelli, 2014, pp. 3-5).

\subsubsection{Between Federalism and Decentralisation}

The regional reforms in Europe have different outputs. The French and Italian pattern of regionalisation was reviewed in section 2.1. In several countries the transfer from the central to the regional governments were more significant. In these countries several key competences of the central governments were regionalised, as well. Therefore the competences of the regional units are close to the competences of a member states of the federation. Although these units are very similar to the member states, the classification is not obvious. In several cases the concept of the unitary state prevail in the national constitution, and in other cases the state nature is questionable. Thus this model can be interpreted as a transitional one.

\subsubsection{A "Quasi" or "De-Facto" Federation and the Regional Development: Spain}

The regional development system of Spain can be interpreted as this quasi-federative model. After the Fall of the Franco regime, during the Democratic Transition the Spanish Constitution of 1978 introduced a strongly decentralised model. The model of this constitution was based on an asymmetric devolution model. The autonomy of the regional entities - the comunidad autonoma - was recognised by the Constitution, but their exact tasks and powers should be defined by the statutes of these autonomies which are organic laws (ley Orgánica). Several comunidad autonoma have special status, especially in the field of cultural autonomy and in the field of the official language of the region. Thus Catalonia (Cataluña/Catalunya), the Basque Country (Pais Vasco / Euskadi) and Galicia have special rights: their regional language is an official language. Formerly these regions had larger autonomy in the field of taxation, public services, regional planning and development (Rodríguez-Arana, 2008, pp. 207-208), but the asymmetry of the Spanish regional system has decreased in the last decades. Now the special autonomy of the policing and the regional language as official language has remained as the major element of the special status of these regions. Thus the Spanish regional reforms were interpreted as a top-down federalisation, and the Estado de las Autonomias (literally translate: State of the Autonomies) as a federative system (Moreno, 2001, pp. 2-4).

Although the wide competences of the regions the Spanish administrative system could not be interpreted as a federal one. The concept of the unitary state is declared by the Spanish Constitution. Therefore the regions are inter- 
preted as regional municipalities with wide competences by the Spanish Constitutional Court - by which the referendum on the independence of Catalonia was declared unconstitutional (Elisenda Casanas \& Rocher, 2014, pp. 27-28). The Spanish regions have legislative powers and they are responsible for the regional planning in the communidad autonoma and the allocation of the development funds - especially the funds cofinanced by the European Union - belongs to the competences of the regional governments (Viver Pi-Sunyer, 2013, pp. 455-457). The original territorial units of the centralised state, the NUTS-3 level counties (provincial) have remained, but their competences are limited and they are focused on the planning issues.

The Spanish model is a strongly decentralised one. The Spanish regions are intepreted legally as local governments, but their tasks and powers are similar to the member states of the federations. Therefore Spain has a quasi-federative model.

\subsubsection{An Asymmetrical Federation (?): The United Kingdom}

The regional planning and development model of the United Kingdom can be interpreted as a transitive and special one. Before the reforms of the 90 s the United Kingdom was a relatively centralised state. The $2^{\text {nd }}$ tier local governments, the counties have several regional planning and development competences but these tasks belonged mainly to the powers of the central government. After the EU Accession of United Kingdom regional reforms occurred. These regional reforms were based on deconcentrating the central powers: the regional bodies were practically agencies of the central government. Such regional agencies were the Government Offices for the (English) Regions (GOR) which were organised in England in 1994 and they were primarily responsible for regional planning and development - especially for the tasks related to the European regional policies. The tasks of the GORs were supported by the regional development agencies which were mainly companies owned by public bodies (Shutt, 1996, p. 92).

The traditional British system has been transformed by the devolution process. The devolution is similar to the concept of the decentralisation, but it is partly different (Cole, 2006, pp. 1-3., Copus et al., 2017, pp. 12-13 and Siket, 2017, pp. 133-135). Firstly, the devolution had different meanings. In the first phase of the devolution, several competences were transferred to the constituent nations of the United Kingdom. Thus the establishment of the legislative bodies and governments of Scotland, Wales and Northern Ireland was interpreted as the devolution of the United Kingdom. This devolution was an asymmetric one: the powers and duties of these legislative bodies and governments are different. Such regional legislative bodies and governments have not been established in England, the powers and duties of these bodies are fulfilled by the Parliament and the Government of the United Kingdom. The regional planning and development tasks in Scotland, Wales and Northern Ireland are performed by these bodies. The newly organised legislative 
bodies and governments have very wide powers which are very similar to the member states of the federations. But the United Kingdom was considered as a "quasi-federation" because traditionally the statehood of these units were not recognised (Burgess, 2006, p. 131). This approach partly changed when Scotland had the opportunity to hold a referendum on the independence. Thus the Scottish statehood was recognised by the permissive act of the Parliament of the United Kingdom (McHarg, 2016, pp. 102-104).

The transfer of powers to the constituent nations of the United Kingdom and thus the "federalisation" of Great Britain is interpreted as a devolution of the British government system. However the (top-bottom) strengthening of the English municipalities (especially the counties and the unitary councils and partly the districts) is a part of the devolution (Copus et al., 2017, pp. 12-14). the different meanings of the devolution the British system can be considered as a transitive one. If Scotland, Wales and Northern Ireland are interpreted as regional entities then it is relatively decentralised, because these units have wide development competences. If the constituent nations could be considered as member states of a federation than the model of the United Kingdom can be interpreted as a centralised, federal system. The counties and unitary authorities have narrow competences in regional development. The majority of the regional development tasks have been centralised, the former atypical - the so called "non-departmental” - bodies responsible for several regional development tasks, the regional development agencies and the regional assemblies (OECD report, 2009, pp. 146-148) were abolished between 2008 and 2012 (firstly the abolition of the regional assemblies begun, then the regional development assemblies were abolished between 2010 and 2012) (Cullingworth et al., 2014, pp. 16-18).

The regional reforms transformed the system of the regional development in several - especially relatively larger - EU Member States. Firstly, the decentralised system is followed by the larger countries of Europe. Regional level municipal bodies became responsible for the major tasks of the regional development in France, Italy and Poland. In Spain and in the United Kingdom a special, quasi-federative system has evolved. The challenges of the economic crisis after 2008 impacted this system strongly: tendencies of recentralisation and concentration could be observed. In France the model was concentrated by the amalgamation of the regions. In Spain the expansion of the regional autonomy has stopped. In England the former non-departmental bodies, the regional development agencies and the regional assemblies were abolished.

\subsection{Federal Model}

The federal states could be interpreted as an independent model. In these countries there are subnational units which have statehood. These entities have wide responsibilities, and obviously the tasks of regional development belong to the competences of the member states of the federation therefore the federal (central) government has typically limited powers in this field. The 
regulation on the municipal system is mainly the competence of the member states, therefore different systems have been evolved. The regional structure of these federation is various.

\subsubsection{Regional Planning Centralised by the Member States of the Federation}

This model is typical in the small federations, especially in Austria (Belgium has a special, more decentralised model, see in point 4.2.). The member states of the Austrian federation, the provinces (Bundesländer) are NUTS-2 ("regional") level entities and they have a one-tier municipal system which is relatively fragmented, having more than 2000 municipalities (Gemeinde) (Neuhofer, 1998, pp. 22-23). Therefore the planning and development competences of the municipalities is very limited: it focuses on the development of the community. The widespread inter-municipal cooperation in the Austrian Länder are mainly common framework for the municipal developments and for the joint application for development aid (Neuhofer, 1998, pp. 567-572).

Therefore the competences of the regional planning and development are centralised by the regional level entities, by the provences. The Länder have statehood, they have unicameral state parliaments (Landtag) and the state government, the Landesregierung which is led by the Landeshauptmann ("Chief of the Province" or "Governor"). In the Austrian system the planning belongs to the tasks of the state parliaments, and the state governments are responsible for the decision-making and the execution of the plans, especially the allocation of the development funds (Adamovich et al., 2014., pp. 60-61 and pp. 194-195). As a result of the New Public Management reforms, several governmental development tasks are performed by the regional development agencies, which are mainly companies (Ltd. - GmbH-and corporation - AG) or legal persons governed by the private law (Halkier, 2012, p. 45).

Similar model evolved in the small German provinces (Länder), especially in the city states of Germany (Berlin, Hamburg, Bremen und Bremerhaven). In these provinces the state parliaments and the state governments are responsible for the regional planning and development. These bodies are not only organs of a federal states but they can interpreted as municipal organs, as well (Musil \& Kirchner, 2012, pp. 92-93).

\subsubsection{Federal Models with Shared Competences Between State and Local Government}

The federal models with shared competences between state and local government is primarily followed by Germany. In the German - decentralised federal system the states (provinces) - which are NUTS-1 level units - are primarily responsible for the tasks of regional planning and development (Chilla et al., 2016, p. 16). These provinces have unicameral parliaments (Landtag) and a state government which is responsible to the state parliament. The ma- 
jor policy-maker at the state level are the state ministries (Milke \& Reutter, 2012, pp. 43-44). The structure of the state government is different, but the tasks of the competences of regional planning and development belong primarily to the portfolio of the state ministries responsible for economics.

Although the main policy makers in the field of regional planning and development are the German states (provinces) the municipal system has significant tasks. Typically the German Länder have a two-tier municipal systems, the second tier is the NUTS-3 level, which are the Landkreise (counties) and the kreisfreie Städte (actually unitary authorities). These municipalities have planning and development competences, as well. In the majority of the German provinces several tasks of the regional planning and development are performed by special inter-municipal associations, by the planning associations (Planungsverbände) which are typically obligatory inter-municipal associations, and their members are the counties (Landkreise) and the communities (Gemeinde) (Erbguth et al., 2015, p. 19. and Brüning, 2013, p. 68). This model has impacted by the New Public Management reforms: regional development agencies (which are mainly companies governed by the private law) were established and the tasks of these inter-municipal associations have been expanded, especially in the field of the organisation of the regional (public) transport (Benz \& Meinecke, 2006, pp. 67-70).

Belgium has a similar system. The unitary Belgium became a regionalised state after the constitutional reform of 1970 . The regionalised state developed into a federal state after the reforms of 1993 which was strengthened by the amendment of the Belgian Constitution in 2001 (Balázs, 2011, p. 276). The member states of the Belgian federations, especially the governments of the regions (Flanders, the Walloon Region and the Brussels Region) as NUTS-1 level entities are responsible for the tasks of the regional development. The local governments, especially the NUTS-2 level provinces (province/provincie) as regional governments have important competences in this field, as well (Wayenberg et al., 2011, pp. 81-83).

The federal states have special structures: the federal units have wide competences in the field of regional planning and development. In Austria the provinces are the major bodies responsible for regional planning and development but in Germany and Belgium these competences are shared between the member states and the second tier municipalities and the inter-municipal associations for performing planning and development tasks. The New Public Management Reforms influenced the model of these countries, as well. During the 1980s and the 1990s regional development agencies have been established which remained after the crisis.

\section{Conclusion}

The municipalities are responsible for the local development but they are important actors of the regional development policies, as well. Although they 
have significant competencies, their roles are different. It depends on the size of the country, the local government system and the general model of the regional development. Thus the centralised, the decentralised and the federal models can be distinguished. In this (review) article the main elements of the administration of the regional planning and development were reviewed.

The administration of regional planning has been strongly influenced by the European integration. Significant resources are provided by the European Structural and Investment Funds and other EU funds. The allocation of these funds was a major task of those countries which have been recipients of these resources. The regional approach of the structural funds was a catalyst of the territorial reforms in several EU Member States. This approach was related to the New Public Management (NPM) paradigm, as well. The decentralisation was one of the major elements of the NPM-influenced reforms during the 1980s and 1990s. Although originally the regional tendencies in Europe were based on the NPM-related reforms these changes were supported by the post-NPM paradigms (especially by the Good Governance paradigm), as well. Thus the cooperation with the stakeholders and with the society has been highlighted by the reforms in the late 1990s and 2000s.

The impact of the European Union funds have been different. In the New Member States the centralised model is the dominant one, because of the smaller size of the countries and the significant role of the EU funds in the regional development of these countries. The allocation of these resources was controlled by the central government and its agencies. In several Member States special hybrid bodies evolved which partly transformed into municipal nature bodies (especially into special inter-municipal associations). Thus the decentralisation was finally stimulated by these funds in these countries (for example in Ireland and Portugal).

After the economic crisis of 2008 new approaches evolved in the administration of regional development. The centralisation and the concentration of the structures was stimulated by the impact of the crisis. This tendency could be observed in the centralised systems, where the former partly decentralised, regional bodies and agencies were abolished (especially in Greece and partly in Hungary), and in regionalised systems where the regional units were merged (in France) or the federal tendencies were stopped (in Spain and partly in Italy). This centralisation was related to the reduced influence of the NPM and to the shifting of paradigm, especially the evolvement of the paradigm of the Neo Weberian State (Pollitt - Bouckaert, 2017, pp. 18-26). Thus the tendencies of "re-municipalisation" and "re-nationalisation" could be observed. In the 90 s and in the 2000s the regional development agencies were mainly established as companies owned by public bodies. In the last decade the system of these agencies have been transformed in several countries (for example in the United Kingdom and in Hungary). These agencies have been abolished or their tasks have been transferred to public bodies, therefore a "re-municipalisation" procedure can be observed. 
It can be concluded that the differences of centralised, decentralised and federal systems have remained, but several transformations could be observed and in several countries the model of the administration changed in the last decades. A convergence can be observed: the competences of the municipal bodies have been strengthened. Firstly the municipal bodies received new competences, especially in the field of the regional planning. In several countries the former central agencies transformed into inter-municipal bodies. Secondly, in the decentralised countries the coordination competences of the central government have been strengthened. These changes were strongly impacted by the regulation on the EU funds and by the EU cohesion and regional policy. 


\section{References}

Adamovich, L. K., Funk, B. C., Holzinger, G. F. And Stefan L. (2014). Österreichisches Staatsrecht. Band 2: Staatliche Organisation. 3. Auflage. Wien: Verlag Österreich.

Adams, N. (2006). National Spatial Strategies in the Baltic States. In N. Adams, J. Alden, and N. Harris, eds., Regional Development and Spatial Planning in an Enlarged European Union. Aldershot: Ashgate, pp. 155-181.

Adshead, M. (2003). Policy networks and sub-national government in Ireland. In M. Adshead, and M. Millar, eds., Public Administration and Public Policy in Ireland. Theory and Methods. London, New York: Routledge, pp. 108-128.

Amorosi, T. and Cinque, P. (2015). Le Province: nuovo Ordinamento ed Organi - Funzioni. In F. Narducci, and R. Narducci, eds., Guida Normativa 2015. Santarcangelo di Romagna: Maggioli, pp. 301-386.

Balázs, I. (2011). Belgium közigazgatása. In K. Szamel, I. Balázs, G. Gajduschek and G. Koi, eds., Az Európai Unió tagállamainak közigazgatása. Budapest: Complex, pp. 271-290.

Bäumer, K. and Kroës, G. (2016). Decentralisation in German Context: An Assesment of Governance Actors and Approaches 'from Below'. In E. Dick, K. Gaesing, D. Inkoom and T. Kausel, eds., Decentralisation and Regional Development. Experiences and Lessons from Four Continents over Three Decades. Basel: Springer International, pp. 57-70.

Benz, A. and Meinecke, A. (2006). Sub-National Government and Regional Governance in Germany. In M. Hoffmann and H. Vincent Wollmann, eds., State and Local Government Reforms in France and Germany. Divergence and Convergence. Wiesbaden: VS Verlag für Sozialwissenschaften, pp. 59-74.

Booth, P. (1996). Controlling development. Certainity and discretion in Europe, the USA and Hong Kong. London, New York: Routledge.

Borrás-Alomar, S., Christiansen, T. and Rodríguez-Pose, A. (1994). Towards a 'Europe of the Regions'? Vision and Reality from a Critical Perspective. Regional Politics and Policy 4 (2), pp. 1-27.

Brüning, C. (2013). Kommunalrecht. In D. Ehlers, M. Fehling, and H. Pünder, eds., Besonderes Verwaltungsrecht. Band 3 Kommunalrecht, Haushaltsund Abgabenrecht, Ordnungsrecht, Sozialrecht, Bildungsrecht, Recht des öffentlichen Dienstes. 3., völlig neu bearbeitete und erweiterte Auflage. Heidelberg: C. F. Müller, pp. 1-109.

Burgess, M. (2006). Comparative Federalism. Theory and practice. London, New York: Routledge.

Callanan, M. (2003). Regional Authorities and Regional Assemblies. In M. Callanan and J.F. Keogan, eds. Local Government in Ireland. Inside Out. Dublin: Institute of Public Administration, pp. 429-446.

Cassese, S. (2010). Il diritto administrativo: storia e prospettive. Milano: Giuffré.

Chilla, T., Kühne, O. and Neufeld, M. (2016). Regionalentwicklung. Stuttgart: Eugen Ulmer.

Christopoulos, D. (1999). Regionalism in Greece. In P. Wagstaff, ed., Regionalism in the European Union. Exeter, Portland: Intellect, pp. 158-166.

Cole, A. (2006). Beyond devolution and decentralisation. Building regional capacity in Wales and Brittany. Manchester: Manchester University Press.

Constantin, D., Goschin, Z. and Dragan, D. (2011). Implications of European Union structural assistance to new member states on regional disparities: the 
question of absorption disparities. In R. Stimson, R. Stough, and P. Nijkamp, eds., Endogenous Regional Development. Perspectives, Measurement and

Empirical Investigation. Cheltenham, Northampton: Edward Elgar, pp. 182-203.

Copus, C., Roberts, M. and Wall, R. (2017). Local Government in England.

Centralisation, Autonomy and Control. London: Palgrave Macmillan.

Cullingworth, B., Nadin, V. Hart, T., Davoudi, S. et al. (2014). Town and Country Planning in the UK. 15th edition. Abingdon, New York: Routledge.

Dantonel-Cor, N. (2007.) Droit des collectivités territoriales. Paris: Bréal.

Deželan, T., Maksuti, A. and Uršić, M. (2014). Capacity of Local Development Planning in Slovenia: Strenghts and Weakness of Local Sustainable Development Strategies. Lex Localis - Journal of Local Self-Government, 12 (3), pp. 547-573.

Elisenda C. and Rocher A. (2014). (Mis)recognition in Catalunya and Quebec: The Politics of Judicial Containment. In J. Lluch, eds., Constitutionalism and the Politics of Accommodation in Multinational Democracies. Basingstoke: Palgrave Macmillan, pp. 46-69.

Erbguth, W., Mann, T. and Schubert, M. (2015). Besonderes Verwaltungsrecht. Kommunalrecht, Polizei- und Ordnungsrecht, Baurecht. Heidelberg: C. F. Müller.

Eurostat, 2017 At <http://ec.europa.eu/eurostat/statistics-explained/index. php/File:GDP_at_current_market_prices,_2006_and_2014-2016_YB17.png> accessed 31 December 2017.

Franchini, C. and Vesperini, G. (2012). L'Organizzazione. In S. Cassese, ed., Istituzioni di diritto amministrativo. Milano: Giuffré, pp. 73-130.

Giersig, N. (2008). Multilevel Urban Governance and the 'European City'. Discussing Metropolitan Reforms in Stockholm and Helsinki. Wiesbaden: VS Verlag für Sozialwissenschaften.

Halkier, H., Danson, M. and Damborg, C. (eds.) (1998) Regional Development Agencies in Europe. London (UK) - Philadelphia: Jessica Kingsley Publishers \& Regional Studies Associations.

Halkier, H. (2012). Regional development agencies, regional policies in the knowledge economy. In N. Bellina, Nicola, M. Danson and H. Halkier, eds., Regional Development Agencies: The Next Generation? Networking, knowledge and regional politics. London, New York: Routledge, pp. 24-51.

Hoffman, I. (2014). The Changes of the Roles of the Hungarian Counties: Towards a One and a Half-Tier System? Lex Localis - Journal of Local Selfgovernment ,12 (3), pp. 393-411.

Hoffman, I. (2015). Bevezetés a területfejlesztési jogba. Második, hatályosított és átdolgozott kiadás. Budapest: ELTE Eötvös.

Hoffman, I. (2017). Bevezetés a területfejlesztési jogba. Harmadik, hatályosított és átdolgozott kiadás. Budapest: ELTE Eötvös.

Hooghe, L., Marks, G., Schakel, A. et al (2016). Measuring Regional Authority. A Postfunctionalist Theory of Governance, Volume I. Oxford: Oxford University Press.

Hughes, J., Sasse, G. and Gordon, C. (2005). Europeanization and Regionalization in the EU's Enlargement to Central and Eastern Europe. The Myth of Conditionality. Basingstoke, New York: Palgrave Macmillan.

Jagielski, J. (2005). Administrative Law. In S. Frankowski and A. Bodnar, eds., Introduction to Polish Law. The Hague: Kluwer Law International, pp. 153-188. 
Jeffrey, C. (ed.) (1997). The Regional Dimension of the European Union. Towards a Third Level in Europe. London: Frank Cass.

Johansson, J. (2000). Regionalisation in Sweden. In J, Gidlund and M. Jerneck, eds., Local and Regional Governance in Europe. Evidence from Nordic Regions. Cheltenham: Edward Elgar, pp. 125-159.

Józsa, Z. (2005). A lengyel regionális reform. In K. Pálné, ed., Regionális reformok Európában. Budapest: BM IDEA, pp. 199-230.

Kacziba, P., Oppe, O. and Pálné Kovács, I. (2016). Az európai területi reformok és tanulságaik. In I. Pálné Kovács, ed., A magyar decentralizáció kudarca nyomában. Budapest, Pécs: Dialóg Campus, pp. 29-61.

Keating. M. and Loughlin, J. (eds.) (1997). The Political Economy of Regionalisation. London: Frank Cass.

Kuhlmann, S. and Wollmann, H. (2014). Introduction to Comparative Public Administration. Cheltenham, Northampton: Edward Elgar.

Loughlin, J. (1997). Regional policy in the European Union. In S. Stavridis, E. Mossalios, R. Morgan and H. Machin,, eds., New Challenges to the European Union: Policies and Policy-Making at the End of the Century. Aldershot: Darthmouth, pp. 439-466.

Loughlin, J., Hendriks, F. and Lidström, A. (2011). Introduction. In J. Loughlin, F. Hendriks, A. Lidström, eds., The Oxford Handbook of Local and Regional Democracy in Europe. Oxford: Oxford University Press, pp. 1-26.

MacCarthaigh, M. (2017). Public Sector Reform in Ireland. Countering Crisis. Cham: Palgrave Macmillan.

Magone, José M. (ed.) (2003). Regional Institutions and Governance in the European Union. Westport, London: Praeger.

Malíková, L. and Jacko, T. (2016). Public Administration Reforms in Slovakia: Reviewing Previous Structures and Adopting a New Model. In S. Guérard and A. Astrauskas, eds., Local Autonomy in the 21st Century. Between Tradition and Modernisation. L'autonomie locale au XXle siècle. Entre tradition et modernisation. Lille: Institut Universitaire Varenne, pp. 285-304.

Mangiamelli, S. (2014). The Regions and the Reforms: Issues Resolved and Problems Pending. In: S. Mangiamelli, ed., Italian Regionalism: Between Unitary Traditions and Federal Processes. Cham: Springer International, pp $1-34$.

Marcou, G. (2015). Où va le système français d'administration territoriale ? In JC. Némery, ed., Quelle organisation pour les grandes régions en France et en Europe ? Paris: L'Harmattan, pp. 25-32.

Marks, G. (1992). Structural Policy in the European Community. In A. Sbragia, ed., Euro-politics: Institutions and Policymaking in the "New" European Community. Washington: Brooking Institutions, pp. 191-224.

Martin, R. (1999). The Regional Dimension in European Public Policy. Convergence or Divergence? Basingstoke: Macmillan.

McCann, P. (2015). The Regional and Urban Policy of the European Union. Cohesion, Results-Orientation and Smart Specialisation. Cheltenham, Northampton: Edward Elgar.

McHarg, A. (2016). The Constitutional Case of Independence. In: A. McHarg, T. Mullen, A. Page and N. Walker, eds., The Scottish Independence Referendum. Constitutional and Political Implications. Oxford: Oxford University Press, pp. 101-126. 
Mielke, S. and Reutter, W. (2012). Landesparlamentarismus in Deutschland - Eine Bestandaufnahme. In: S. Mielke and W. Reutter, eds., Landesparlamentarismus. Geschichte - Struktur - Funktionen. Wiesbaden: VS Verlag für Sozialwissenschaften, pp. 23-66.

Moreno, L. (2001). The Federalization of Spain. London, Portland: Frank Cass.

Musil, A. and Kirchner, S. (2012). Das Recht der Berliner Verwaltung. Unter Berücksichtigung kommunalrechtlicher Bezüge. Dritte, überarbeitete und aktualisierte Auflage. Heidelberg: Springer.

Neuhofer, H. (1998). Gemeinderecht. Organisation und Aufgaben der Gemeinde in Österreich. Zweite, völlig neubearbeitete Auflage. Wien, New York: Springer.

OECD Report (2009). Governing Regional Development Policy. The Use of Performance Indicators. Paris: OECD.

Pálné Kovács, I. (2014). Failed Rescaling of Territorial Governance in Hungary: What Was the Gist? In S. Nunes, and J. Buček, eds., Fiscal Austerity and Innovation in Local Governance in Europe. London, New York: Routledge, pp. 95-112.

Piattoni, S. (2008). The Committee of the Regions: multi-level governance after enlargement. In E. Best, T. Christiansen and P. Settembri, eds., The Institutions of the Enlarged European Union. Continuity and Chang. Cheltenham, Northampton: Edward Elgar, pp. 162-182.

Ploštajner, Z. (2005). Slovenia: Different Type of Old Industrial Regions. In B. Müller, M. Finka and G. Lintz, eds., Rise and Decline of Industry in Central and Eastern Europe. Berlin, Heidelberg: Springer, pp. 213-228.

Pollitt, C. and Bouckaert, G. (2017). Public Management Reform. A Comparative Analysis - Into the Age of Auterity. Oxford: Oxford University Press.

Ravšelj, D. and Aristovnik, A. (2017). R\&D Subsidies as Drivers of Corporate Performance in Slovenia: The Regional Perspective. DANUBE: Law and Economics Review 8 (2), pp. 79-95.

Regulation (EU) No. 1303/2013.

Rodríguez-Arana, J. (2008). Derecho Administrativo Español. Tomo I. Introducción al Derecho Administrativo Constitucional. Olieros: Netbiblo.

Schrijver, F. J. (2006). Regionalism after Regionalisation. Spain, France and the United Kingdom. Amsterdam: Amsterdam University Press.

Sharpe, L. J. (1993). The Rise of the Meso Government in Europe. London: SAGE.

Siket, J. (2017). A helyi-területi önkormányzatok közigazgatási autonómiája Magyarországon. PhD Dissertation. Szeged: University of Szeged, Faculty of Law.

Shutt, J. (1996). Appraising Europe in the Regions 1994-1999: A Case Study of Recent Experiences in Yorkshire and Humberside. In J. Alden and P. Boland, eds., Regional Development Strategies. A European Perspective. London, Bristol: Jessica Kingsley Publishers, Regional Studies Associations, pp. 86-106.

Swann, J. (2012). Parlements and Provincial Estates. In W. Doyle, The Oxford Handbook of the Ancien Régime. Oxford: Oxford University Press, pp. 93-110.

Swianiewicz, P. (2013). Poland: creeping regionalization of the unitary state. In J. Loughlin, J. Kincaid, and W. Swenden, eds., Routledge Handbook of Regionalism and Federalism. Abingdon, New York: Routledge, pp. 331-340.

Szalai, É. (2004). A területfejlesztési igazgatás és az építési jog alapjai. In L. Ficzere and I. Forgács, eds., Magyar közigazagtási jog. Különös rész európai uniós kitekintéssel. Budapest: Osiris, pp. 219-259. 
Tatham, M. (2016). With, Without or Against the State? How European Regions Play the Brussels Game. Oxford: Oxford University Press.

Teles, F. (2016). Local Governance and Inter-municipal Cooperation, Basingstoke, New York: Palgrave Macmillan.

Tosics, I. (2016). A közelmúlt város-és térségpolitikai korszakai. In M. T. Horváth and I. Bartha, eds., Közszolgáltatások megszervezése és politikái. Merre tartanak? Budapest - Pécs: Dialóg Campus, pp. 665-679.

Viver Pi-Sunyer, C. (2013). The Distribution of Competences in Spain a Year After the Ruling 31/2010 of Constitutional Court: The Reaffirmation of the Unitary State? In: A. López-Basaguren and L. Escajedo San Epifanio, eds., The Ways of Federalism in Western Countries and the Horizons of Territorial Autonomy in Spain. Heidelberg, Berlin: Springer, pp. 451-466.

Weber, T. and Köppert, V. (2015). Kommunalrecht Bayern. 3., neu bearbeitete Auflage. Heidelberg: C. F. Müller.

Wollmann, H. and Bouckaert, G. (2006). State Organisation in France and Germany between Territoriality and Functionality. In V. Hoffmann-Martinot and H. Wollmann, eds., State and Local Government Reforms in France and Germany. Divergence and Convergence. Wiesbaden: VS Verlag für Sozialwissenschaften, pp. 11-38. 